\title{
The Risk Takers: The Support Faculty Participants in Integration Initiatives Say They Really Need
}

\author{
By Denise Ann Vrchota ${ }^{1}$
}

\begin{abstract}
This qualitative study reports the concerns of faculty in one food science department as they integrate communication competencies into their classes. The results of the study prioritized self-reports from faculty regarding the challenges they experienced while integrating communication activities into their classes; the nature of the concerns and accompanying recommendations may be generalizable to integration efforts in other disciplines. Two areas of concern that emerged are: faculty were challenged by logistical issues such as developing assessment instruments and assignments and by developing group activities; second, the risks they took by teaching an area outside of their disciplinary expertise caused them to question their preparedness to teach another discipline in these ways: they felt they were losing control of their own disciplinary content and were not prepared to help students with group activities or to give students useful feedback. Several issues emerged for the consideration of agents of integrations and researchers in this area, among them, that integration is a process rather than an event, and agents of integration are visitors who must respect the traditions of the disciplines within which they work.
\end{abstract}

Key Words: integration, higher education, scholarship of integration, interdisciplinarity, pedagogy

"Should I put a different question in?"

"Do they stay as pairs or do I make them switch partners?"

"So at what point do they do...?"

"Is it better for one person to handle all the questions or should all three of them answer?"

"Am I at the point where I should ask them?"

The questions were asked of me by faculty participants during a department integration initiative. Educational integration is generally defined by researchers as merging disciplinary content in order to produce new knowledge (Hovland, Anderson \& Ferron, 2015; Huber \& Hutchings, 2004). Integration of disciplines in higher education is crucial in order to prepare students to meet the challenge of and become contributors to the professional, social, and cultural communities in which they will live their lives. In these contexts, they are likely to meet unanticipated challenges for which expertise from another domain is crucial to success. Challenges for which the process of integrating knowledge from diverse disciplines is an increasingly necessary life skill that is currently deemed more important than knowledge in only one discipline.

This means that integration is not only a life skill but is also a teaching skill. Faculty become key when introducing and developing classroom activities through which students practice and acquire the integration competencies they will transfer to their own lives. Faculty, experts in their own disciplines, must have guidance and practice to integrate the knowledge of other

\footnotetext{
${ }^{1}$ Communication Studies Program, Department of English, Iowa State University, 344 Carver Hall, Ames, IA 50011,vrchota@iastate.edu.
} 
disciplines into their own areas. Despite widespread agreement in the integration literature regarding the value of integration efforts to students (American Association of Colleges \& Universities (AACU), 2015; Bordoloi \& Winebrake, 2015; Carnegie Foundation for the Advancement of Teaching, 2004; Dalyrymple \& Miller, 2006; Hovland et al., 2015; Huber \& Hutchings, 2004; Huber, Hutchings, \& Gale, 2005; Huber \& Morreale, 2002; Klein, 2005; Newman, Carpenter, Grawe, \& Jaret-McKinstry, 2015), the research remains largely silent on faculty preparation for these efforts. At a time when institutional accountability may be defined in terms of outcomes assessments, student competencies are of central concern. Also of concern should be the preparation of the faculty who are responsible for instilling integration competencies in their students. The absence of research that acknowledges the vital role of faculty in the process of preparing students to integrate knowledge is the issue addressed by the present discussion.

The purpose of the present study is to identify the challenges faculty in one discipline, food science, experienced when integrating oral communication activities into their curriculum. The study, part of a larger study, was conducted as the faculty embarked on an initiative to integrate oral communication into their curriculum. Although experts in their respective discipline, the faculty had little formal training in oral communication, a situation similar to integration efforts in other disciplines. The results of the present study are perhaps generalizable to and supportive of other integration efforts for these reasons: first, because little previous research has investigated the area of faculty concerns during an integration initiative, the results of the present study provide baseline data upon which to build studies of other integrations. Second, although the faculty participants in the present study were experts in their own discipline, the nature of the questions and concerns they raised when integrating oral communication into their discipline may provide insights regarding the needs of faculty participants in other integrations that will prove useful for agents of those efforts. In the following section I will discuss the integration movement and present a brief history of oral communication integration followed by an account of the methodology and results of the study. On the basis of the results, I will make suggestions germane to agents who guide integration efforts and to researchers who study these efforts.

\section{Theoretical Framework}

\section{Integrative Learning}

The concept of integrative learning originated in Boyer's (1990) scholarship of integration, defined as "putting into perspective isolated facts; making connections across disciplines (p. 18)," according to Kern, Mettetal, Dixson, \& Morgan (2015). In the classroom, integrative learning refers to learning experiences that cut across disciplines in order to make connections of the knowledge of those disciplines (Boyer, 1990; Dalrymple \& Miller, 2006; Hovland et al., 2015; Huber \& Hutchings, 2004; Huber \& Morreale, 2002; Kern et al., 2015; Klein, 2005). Other sources describe integrative learning experiences to include those in which students connect skills and knowledge from multiple sources and experiences, apply theory to practice, utilize diverse viewpoints, and understand issues contextually (American Association of Colleges and Universities (AACU) \& the Carnegie Foundation for the Advancement of Teaching, 2004).

Integrative efforts have become more prevalent in recent years. For example, the AACU (2015) noted “a growing national emphasis on fostering undergraduate students' integrative learning through multiple forms of engaged educational experiences.” Researchers and educators agree there is a need for integrated learning in higher education for several reasons. Integrative learning is crucial to students' abilities to live as local and global citizens in order to respond to 
complex social, cultural, and economic challenges, and to meet corresponding new opportunities that present themselves; integrative learning principles enable students to give meaning to fastchanging, complex, and easily accessed knowledge because, as research becomes more discrete, integration is necessary to make knowledge more meaningful; the ability to integrate knowledge responds to increasing demands for accountability amidst fluctuating national priorities (AACU and The Carnegie Foundation for the Advancement of Teaching, 2004; Boyer, 1990; Carnegie Foundation for the Advancement of Teaching, 2004; Dalrymple \& Miller, 2006; Huber \& Hutchings, 2004; Huber, 2002; Huber \& Morreale, 2002). The bottom line is that today's challenges are too complex to handle for a student who has studied the content of only one discipline (Price, 2011); the ability to integrate disciplinary knowledge is now an imperative component of undergraduate education.

Of particular interest to the present discussion is the role of the faculty participants who are placed in both demanding and vulnerable positions with few solutions provided to resolve their issues. In terms of their disciplinary membership, there is little guidance as to the process by which faculty from differing disciplines should collaborate on integrative projects or how they might work to shed their disciplinary allegiances and traditions. Appropriate pedagogy and assessment techniques for integrative efforts are unclear and may need to be negotiated across disciplines. In one study participating faculty were asked to name the challenges they experienced in their new roles: among their requests was assistance with assessment (Considine, Mihalick, Mogi-Hein, Penick, \& Van Auken, 2014). Similarly unclear are methods for transferring learning to other settings. Faculty may also need training in areas such as reflecting on or synthesizing knowledge in order to model those actions for students (AACU \& The Carnegie Foundation for the Advancement of Teaching, 2004; Bordoloi \& Winebrake, 2015; Dalrymple \& Miller, 2006; Hovland et al., 2015; Huber, 2002; Huber \& Hutchings, 2004; Huber et al., 2005; Huber \& Morreale, 2002; Klein, 2005; Newman et al., 2015). The present discussion intends to identify areas of support needed by faculty in integration initiatives, by examining the needs of faculty in one food science department as they participate in an effort to integrate oral communication into their curriculum. Knowing faculty needs and providing for those needs may resolve, or reduce, some of the faculty-related issues identified by researchers while recognizing the crucial role played by faculty and offering support to them for their work in integration initiatives.

The present study recognizes the integral role played by faculty in integration efforts. They are central to exceedingly complex efforts that may include administrators, members of other disciplines, and students; faculty must modify the curriculum and even their own classroom protocols; they must model integration activities for students and, in turn, may experience the repercussions of their efforts from students. Dannels (2010) notes that faculty involved in integration efforts must be risk takers; however, despite the centrality of their positions, few research efforts have sought to know the needs faculty experience during integration efforts in their risk-taking capacities. For the agents of integration, knowing these concerns offers insights that inform the training and practice participating faculty need in order to enable them to provide experiences that benefit students and contribute to a strong integrative effort.

\section{Tradition of Communication Integrations}

The purpose of the present study is to identify the needs of food science faculty as voluntary participants in the integration of oral communication competencies in their curriculum. The value to the present study lies in the knowledge gained by communication faculty working with faculty in other disciplines that dates to 1976 (Cannon \& Doyle, 2005; Cannon \& Roberts, 1981). The 
experiences of four decades have resulted in a tradition in the communication discipline that guides in integration efforts with other disciplines (see, for example, Cronin \& Grice, 1993; Cronin, Grice, \& Palmerton, 2000; Dannels, 2001: Dannels \& Housley Gaffney, 2009; Morreale, ShockleyZalabak \& Whitney, 1993; Steinfatt, 1986; Strohmeier, Novak, Stratton, \& Leipzig, 1992; and Weiss, 1990). To date, studies of communication integrations are available for the disciplines of engineering (Dannels, 2002, 2003; Dannels, Anson, $\quad$ Bullard, \& Peretti, 2003; Darling, 2005; Darling \& Dannels, 2003), design (Dannels, 2005; Dannels, Gaffney, \& Martin, 2008; Dannels \& Norris Martin, 2008; Housley Gaffney, 2015; Morton, 2006; Morton \& O’Brien, 2005), public education (Smith, 2005), dietetics (Vrchota, 2011) and food science (Reitmeier \& Vrchota, 2009; Vrchota, 2015a; Vrchota, 2015b).

Prior to my involvement with the food science department, I was part of a group of crosscurricular consultants from writing and communication programs working to implement a university wide communication across the curriculum initiative. The cross-curricular consultants worked with faculty in other disciplines to integrate communication activities into their curricula. Although our work was viewed as a service to our colleagues, we were compensated with course release time and occasional professional development funding. The disciplines in which I consulted included engineering, veterinary medicine, design, kinesiology, and food science. In my work with faculty I listen carefully to learn their disciplinary traditions in order to understand the connection of oral communication and their discipline and to gain an understanding of the role of communication activities in classes and in the professional preparation of their students, a characteristic common to the tradition of communication consulting.

The objective guiding the present study is to determine the concerns and needs of faculty in one food science department as they engage in the process of integrating communication activities into their classes. The results are anticipated to contribute to the integration research repertoire in an area where few studies are available. Because the purpose of the study identifies the concerns of faculty as they engage in integrating a new and potentially unfamiliar discipline into their own area of expertise, it is anticipated the results would be generalizable to faculty in other disciplines who participate in similar integration efforts. The following section describes the research site and the data collection and analysis.

\section{Methodology}

The present investigation was conducted in the Department of Food Science and Human Nutrition at a Midwestern research university. The study is part of a larger study in which I examined the connection of oral communication traditions and the food science discipline (for other results of the study, see Vrchota, 2011; 2015a; 2015b).

\section{Participants}

The sixteen self-selected faculty participants, thirteen females and three males, are affiliated with one of three programs in the department where there is mingling of teaching assignments, research collaborations, and common curriculum requirements. Although the small number of participants is not, as in many emic-focused ethnographic studies, statistically representative, they make up a purposeful sample (Patton, 2002) in that they are senior members of the discipline and the profession and their views represent the values and practices of their field. Eleven hold PhD's in their respective fields, and five have masters' degrees. Twelve of the participants are tenured or tenure-eligible and the remaining four are non-tenure- eligible. They have been members of the 
food science discipline for an average of 21 years (a range of 10 - 36 years) and of the food science profession for an average of 29 years (a range of 18-43 years). Their work has earned them national and international reputations. They are highly published in prestigious scientific journals; several own patents. In addition to their research activities, they are active participants in the teaching initiatives of an engaged department. Five have received highest honors from the university and the state board of regents for their contributions to the food science discipline, the university, and higher education within the state. In order to meet the mandates of the American Dietetics Association (2009) and the Institute of Food Technologists (2011), that require accredited programs to prioritize communication in the professional preparation of students, the participants of this study voluntarily planned and implemented, with the support of their administration, an initiative to integrate oral communication into their department. The research presented in this discussion is based on that initiative and represents the commitment of the participants to the education of their students.

\section{Researcher Role}

My association with the FSHN Department began when I was invited to conduct a series of communication professional development workshops for the faculty and remain in the department for one year in order to consult with faculty as they developed and integrated communication activities into their classes. On the basis of their workshop participation, I found the faculty willing to articulate the concerns and challenges they experienced in their integration efforts. Those who attended all of the communication workshops were invited to participate in the larger study in which I examined the oral genres in use within the curriculum. The sixteen voluntary participants represented $60 \%$ of the faculty attending the workshops.

\section{Data Collection}

After receiving approval from the university institutional review board, individual interviews were conducted with the participants at their convenience and choice of location, typically their offices. The letter accompanying the consent form listed four topics that would be discussed: 1) oral communication competencies students need for disciplinary success; 2) oral communication competencies required of students for professional practice; 3) assessment procedures for oral communication activities; 4) faculty concerns about their efforts to develop communication activities for their classes and areas or support needed to benefit their efforts. The participants' responses to the last topic became the focus of the present discussion.

In addition to the faculty interviews, I also observed a minimum of one class taught by each participant, taking notes containing my observations; examined documents such as course syllabi and assignments, noting communication assignments and the events that prepared students for those assignments; and engaged in informal consultations with faculty as they developed, integrated, and reflected on communication activities for their classes.

\section{Data Analysis}

For the study I chose to construct an emic (Patton, 2002) understanding from the words and views of the faculty of the challenges experienced as they developed and implemented oral communication activities into their classes and across their curriculum. The presentation of the data is constructed as an iterative analysis (Tracy, 2013) that enables connecting the perspectives of the participants with researcher reflections. My reflections are found in the results section where I contextualize the concerns and needs of the faculty participants within the framework of the larger study of which the present study is a part.

Journal of the Scholarship of Teaching and Learning, Vol. 16, No. 6, December 2016. 
The results of the faculty interviews were analyzed inductively according to a flow model (Miles \& Huberman, 1994) in which the data are reduced, arranged, and interpreted. After reading the interview transcripts, the data were reduced to include all statements (a statement was described as a phrase, sentence, or paragraph of any length devoted to a single topic) that registered faculty concerns regarding the conceptualization, development, facilitation, or assessment of any oral communication activity in their classes. The resulting data totaled 175 statements, or approximately $20 \%$ of the total number of data units collected for the larger study. After reducing the data, initial coding was conducted using "tabletop categorization” (Saldana, 2009, p. 188), a hands-on process during which the researcher handwrites code labels on the data, and physically arranges the data units according to their codes. The initial coding revealed faculty concerns about specific oral genres, such as groups or public speaking, and processes, such as giving students feedback. Further examination of the categories resulting from the coded data disclosed that, within the initially identified categories, the foci of the data differed in important ways that further defined the meaning of each unit. For example, some data units in the genre category posed questions about developing group activities, whereas others reflected instructor concerns regarding their own preparation to teach students to work in groups. A second coding identified the foci of each data unit as "communication activities" or "faculty reflections" and these became the main themes of the data analysis. Data coded to each of the main themes were further examined and coded to reveal sub themes.

After the themes and subthemes were identified, an independent coder was given $10 \%$ of the data units to code in order to determine whether the theme and subtheme categories were accurately described and to confirm they were distinguished from one another. Minor inconsistencies were reworked. Next the independent coder checked my work on the completed coding with a resulting inter coder reliability of .93 (Reinard, 2008). Results of the study are presented in the next section.

\section{Results}

The data analysis resulted in two main themes: "communication activities" and "faculty reflections," that represented 53\% and $47 \%$ of the total data units respectively. The first theme, "communication activities," reveals the concerns of faculty as they design classroom activities intended for their students to acquire and practice communication competencies. Two sub-themes resulted from the data coded to the first theme, named here as "managing logistics" (59\% of data coded to theme one), and "developing group activities" (41\% of data coded to theme one). The second theme, "faculty reflections," presents faculty perceptions of their own preparedness to integrate oral communication activities into their classes. Three sub-themes resulted from the data coded to the second theme. Their names and the percentage of data from the second theme coded to each subtheme are: "losing control (38\%)," "guiding groups (35\%)," and "giving feedback (27\%).”

\section{Theme One: Communication Activities}

The primary area of faculty concerns, communication activities, contained 53\% of the total data units and resulted in two subthemes, named here "managing logistics" and "developing group activities.” As I interviewed and consulted with faculty, I learned their courses already contained communication assignments, predominately presentations or group activities.

Presentation assignments were used as the channel through which students presented the results of laboratory testing or food products they prepared (See Appendix 1 for sample 
assignments). In addition to detailed assignments, the students also received rubrics for use as supplementary guides as they prepared their presentations (See Appendix 2 for sample assessment instruments). One presentation assignment for a food production laboratory advised students they were not giving a cooking demonstration but an oral presentation of the food product they prepared in class. The assignment also instructed them to include in the content "sensory attributes of the [food] product including appearance, flavor, and texture." The corresponding rubric for the assignment designated students to "speak clearly, in complete sentences with appropriate volume, good eye contact, and appropriate pacing;" they should also use "appropriate sensory evaluation terms." Despite what seemed to be thoroughly constructed presentation assignments and accompanying rubrics, faculty still posed questions about the logistics of the assignments such as their organization and procedures related to feedback and assessments, both of which are discussed in the subtheme "managing logistics."

Unlike the presentation assignments that contained requirements directed at both content and structure, group activities prioritized the charge of the group rather than the structure and process needed to work in a group (See Appendix 1 for sample assignments). For example, one instructor assigned groups to conduct a complex testing procedure with samples of ground beef. A minimum number of tests were to be performed on the samples but students were encouraged to perform other tests they felt were needed. As the instructor described the assignment, she commented that "usually they do far more [tests] than the minimum," but in doing so, the students found there was insufficient time to complete the assignment. The example implies that students proceeded through the assignment on an ad hoc basis rather than through an initial planning of the activity. In this case, as in others, information about the group process was not part of classroom preparation. The assessment instruments in use to evaluate group work (See Appendix 2 for sample assessments), typically described expectations of individual members or encouraged member selfreflection, but often did not state expectations of the group process, as evidenced by this item taken from a rubric for group assignments:

The group [members] functions well together. Tasks are divided equitably and there is a good distribution of effort. All members are challenged and feel their contributions are valued. Team members consult with each other continuously. Products are group, rather than independent, efforts.”

According to their questions, the faculty were aware of disconnects of preparation and expectations of students in their group activities. These are discussed in the second subtheme named "developing group activities." They also wanted to develop more precise rubrics for use with group activities and these concerns are discussed in "managing logistics.

Managing logistics. The assessment of oral communication activities and the development of assignments for them, particularly for public speaking and group work, were the main topics coded to the "managing logistics" area, resulting in 59\% of the data coded to the communication activities theme. The preparation of assessments for group activities seemed particularly challenging to the faculty, many of whom were experiencing an initial awareness of the complexity of group work and the role of communication in it, as indicated by these individuals: 
Having had this student come in with her complaint today [about the lack of coordination in a group] reinforces this assignment is about group interaction and I need to find a way to assess that.

If I had, you know, more of a rubric set up to say "these are the elements [of group work]," you know, well that's one issue. That's not the only issue.

Faculty also began to realize they had not previously assessed group processes but only on the project on which the group was working. They began to understand an assessment should capture both content and group process, the case with the instructor whose students tested ground beef:

Out of a hundred points, twenty points is going to be lab performance and team work, so it could be a swing of six or eight points if you have a member that's weak vs. one that's strong, out of the hundred. I guess what I need to do is work on this. That's the one question I had.

Questions also emerged regarding assessments for presentation assignments. Traditionally in the food science department, student speakers would conduct a self-assessment but they would also receive assessments from a number of different individuals. The faculty member whose students presented information about different food oils questioned the weights of different individuals' assessments in figuring the speaker's grade:

Last year it was just us and the TA's that evaluated but this year, do we have each individual person [evaluate]? We'll have to decide how much of that is weighted in.

They also realized the learning value of the assessments for the student speaker, as indicated by a faculty member whose students gave brief recaps of information from classroom nutrition lectures:

The person who's giving the feedback could at least write something down and the person who's receiving the feedback could also say 'this is how I responded to that' or something? I don't know. I'm not sure.

And the effectiveness of group members working on a new product development to consider:

I want to incorporate a template for students to answer questions about how the group was functioning and give some sense of 'how do I know if we're functioning well and what can I work on.' So I think it would definitely be something I need to figure out how to do.

Although faculty had developed assessments previously for presentations and group work, the questions they posed seemed to reflect a new understanding of the communication disciplinary content and the understanding that assessments could also be learning experiences for students, as indicated by one individual who requested: "Statements or questions that I can use to guide responses of my classes as they critique people.”

When developing assignments, faculty questions were largely directed to wording and the arrangement of activities in order to attain a specific response from students, the case of this 
instructor developing an assignment where students took sanitation readings on food processing machinery:

So if the question were worded 'give examples of how you worked effectively,' what if they didn't think they worked effectively? Then what would they say or 'do you think you were effective and give examples of why you were or weren't?'

Or the instructor who designed an assignment for a shift manager informing the incoming shift manager the work accomplished in the earlier shift:

So I'm wondering whether you think I should make some changes in the wording, put in different questions, take some out, what's your reaction?

Other concerns reflected a need to determine the appropriate pedagogy for facilitating a communication activity, the case with an instructor developing a role play for students to practice communicating dietary information to health care professionals:

Should we do the modeling before they even go out or should we wait and do the modeling of those two different scenarios when they come back and say, 'o.k., how many of you have experienced either of these scenarios?'

Another faculty member wanted students to apply information they learned through student presentations into the laboratory assignments following the presentations:

Maybe we can do group presentations between each of their lab experiments? Would that work o.k.?

Developing group activities. Concerns directed at the development of group activities contributed $41 \%$ of the data coded to the first theme "communication activities." The prevalence of concerns about groups may be due to the practice of food science professionals conducting much of their work in groups in order to develop food products, consult with health care professionals, and collaborate on research teams. Prior to the faculty participation in the communication professional development workshops, their preparation of students to work in groups was simply to give them a group assignment without instruction, a not uncommon approach used in many disciplines. Following their participation in the workshops, faculty goals for students' group activities reflected an increased awareness of the complexity of the group process but they still expressed concerns about achieving group objectives. One concern expressed by faculty was for ways to prepare students to cultivate the capability to transform themselves according to group needs. One faculty member reflected on a disappointing group experience in a microbiology laboratory:

But I was hoping they would be able to sort of step back and look at how they interacted with the different people in their group. If they would think about 'this person really was never very prepared and so I had to be the leader with this person. But this person was really prepared and so I was the follower.' Do you think that's too much to expect? 
They also became able to detect when things were not going well in a group, yet they were uncertain as to how to respond or what earlier arrangements might be implemented to avoid problems that emerged, such as this observation of groups in a food processing class:

I had a group where one of the people was working full time and she knew all this stuff [about food processing]. She had two people with her and she just told them, 'o.k. you do this and you do that...' she just ran the group. I don't think that was a very good experience for any of them.

These problems appeared to represent a tension resulting from the acquisition of new knowledge about group process combined with their previous approach to group work. In addition, the faculty also expressed concerns of what I would describe as a more easily determined issue, the membership size of groups. Rather than considering the goal of the group assignment, faculty often arrived at group membership through other considerations such as the potential configurations of members, exemplified by this food chemistry laboratory instructor:

The other section has eight people in it and I was thinking rather than making two groups of three and one pair or maybe I'd be better off to do two groups of four in that section. But I had groups of four in the past and yeah, it became two and two, it was almost like two pairs working together.

The rationale of the instructor to avoid an even number of group members was not unreasonable but another method to determine group size would be to consider the assignment for the group, determine the member roles needed to complete the charge, and set the membership based on that need.

\section{Theme Two: Faculty Reflections}

Data coded as "faculty reflections" contains observations by faculty participants describing perceptions of their own preparedness for developing and implementing communication activities. The data coded to this theme represented $47 \%$ of the total data units and include three subthemes named here as: "losing control," "guiding groups" and "giving feedback." The willingness of the faculty to disclose their personal reflections revealed, in many instances, their perceptions of a lack of preparedness to develop and implement activities from another discipline into their own area of expertise. These self-reflections were valuable to me as I assisted them with the integration.

Losing control. The primary concern of faculty, resulting in 38\% of the data coded to theme two, was a perceived loss of control over dissemination of disciplinary knowledge in classes due to the inclusion of communication activities. Their participation in the integration effort was evidence of their commitment to communication in their curriculum, but a sense of losing control prevailed; they appeared to believe they were jeopardizing their own discipline, and, by virtue of their disciplinary connections, themselves. I interpreted several revelations from faculty as expressions of their anxiety about the integration. One expression noted a perceived loss of control over scheduling of course content when communication activities were integrated, as one individual explained:

And so I would need to at least double the amount of lecture time, well, maybe one and a half times, if I really were going to do some related communication activity or 
something that reinforces what we're learning every single time. And I do have frustrations about this.

The faculty also expressed frustration about the corresponding lack of control over student learning they perceived to be a result of communication activities:

All this group stuff takes more time and it never reached the conclusion that I thought we were going to get to. So we never got to that end yet. So it's still hanging out there. When will they learn about this idea?

Although the frustrations occurred in the context of losing control of their own disciplinary content, their remarks also reveal a realization that oral communication serves as both a communication competency for students and a pedagogical approach. With the disclosure of the instructors' frustrations, my role expanded to assisting the faculty in the implementation of communication genres as pedagogy, as a means of effectively helping students learn food science concepts.

Guiding groups. The emergence of group subthemes in both main themes indicates the crucial role played by groups in the food science discipline. Guiding group activities, totaling $35 \%$ of the data coded to theme two, was a frustrating area for the faculty. Many of them brought professional experiences working in groups to their classrooms, but they concluded these experiences did not transfer well to the new content they learned in the professional development workshops. There were several challenges expressed, such as helping students learn group processes:

I've felt that I've not done a very good job giving the students some help in handling group dynamics, being able to solve problems within the group.

And:

It's difficult because you have other teams [groups] that may be working fine, and then, you have one that's not working well. You visit with them and you talk about strategies, but (sighs).

A perhaps unusual contradiction that emerged was that while the faculty expressed uncertainty about how to help students in groups, they were also unsure about the extent to which they should prescribe or teach group process rather than allowing students to find their own way:

I could say, 'this is the way I think you should be organized.' But that's not necessarily the only way to be organized. And so if I start defining, and that's why I've kind of hesitated to do that because I think, why should I impose my rather anal-retentive mind on these students, you know?

Group work in food science is a privileged genre in the food industry. This data reveals that despite traditional professional and disciplinary approaches to group work, the faculty appeared reluctant to provide instruction to students for professional preparation. At the same time, they were disappointed in students' participation in group activities.

Giving feedback. The expression of faculty concerns when giving student feedback in response to communication activities resulted in $27 \%$ of data coded to theme two. On the basis of my experience, giving feedback about students' communication activities is often a challenge 
to faculty in other disciplines because it can be difficult to separate the student from the communication; thus, faculty may feel they are critiquing personal qualities of students. The tentativeness regarding feedback may also signal an area where faculty simply need more information about the discipline about which they are giving feedback. In the case of the present discussion, the concern surrounding feedback seemed to be about the act of giving feedback rather than demonstrating a lack of knowledge about communication. For some, it was difficult to provide constructive feedback:

Biggest problem I had was when people do a great job, it's great. But when people do a poor job, it's really hard not to be critical. At the same time, I'm worried about I've got this person up here and they just recapped the lecture and the way they put it was really wrong. So to correct the misinformation in a nice way is hard.

For others, the challenge was finding ways to encourage continued good work:

I think I can do a pretty good job of identifying or describing why an answer may not be quite thorough enough. But it's the positive flip side. I have a tendency to write 'great' or 'good point' or 'nice work' instead of just taking a little extra time about why that is good.

As evidenced by the reflections presented in the second theme, the faculty who participated in this study were and are risk takers who forged ahead to implement communication activities into their classes despite their self- reported inadequacies. More importantly, their risk-taking also gave them the courage to reveal their vulnerabilities, information that helped me to know what to provide in my work with them.

The following section discusses the results, suggests issues which are generalizable to integration efforts in other disciplines, and lists future research directions.

\section{Discussion and Implications}

The objective of the present study is to contribute to the integration research by acquiring a baseline knowledge of the challenges experienced from the voices of disciplinary faculty as they participate in an integration, an area that has been examined only tangentially in previous studies. Many of the concerns revealed were not markedly unusual from concerns faculty in any discipline might experience when teaching a new class or developing a new assignment. Because these concerns emerged as part of a systematically conducted qualitative study, the seemingly pedestrian nature of the concerns merits consideration by agents of integration and by researchers who study integration efforts. Five conclusions result from the present study:

First, faculty are critical to the integration process. That the food science faculty participants in the present study were the instigators of the integration was a huge benefit to me, to students, and to the curriculum. Despite their support of the initiative, crucial faculty concerns that extended to their disciplinary cores emerged, revealed in the second theme to emerge from the data analysis, "faculty reflections." The issues expressed in the subtheme "losing control," for example, might undermine even the strongest integrative efforts. The self-doubts that emerged from the remaining subthemes, "guiding groups," and "giving feedback," if not addressed, could manifest themselves in classroom activities in ways that minimize student learning outcomes. For agents of integration, it is imperative to identify and address faculty concerns, particularly those 
which may be disclosed in more subtle ways. Future research would focus on the identification of faculty concerns that appear across integration efforts (such as faculty rewards or time issues) and work to find responses to them.

Second, an integration is a process, not an event. Initially I was unprepared for the number of concerns about assessments and assignments that emerged from the data analysis in comparison to more anticipated "big picture" items. After giving these results additional thought, however, I believe these concerns were big picture items because the faculty were delivering their disciplinary content of food science in ways that differed from their usual approach. The emergence of questions about assessment and assignment issues emerged when faculty encountered the need to know about them, not necessarily during a workshop. From this experience, I learned that agents of integration cannot simply deliver disciplinary content in one workshop and assume faculty will "get it;" they must work with faculty as the curricular and corresponding learning needs arise. Two recommendations result: first, agents must anticipate and be responsive to ongoing questions about the application or synthesis of new content into existing disciplinary content. Second, similar to students acquiring new knowledge in classes, faculty who receive new knowledge resulting from an integration are also learners who require opportunities to work with, reflect upon, and question what they are learning. Future research would identify appropriate methods for use by agents of integration to work with faculty participants to acquire and apply new knowledge.

Third, integration efforts occur amidst differing pedagogies. Shulman (1987) identifies knowledge domains that are necessary in teaching, among them content knowledge (the knowledge base of the discipline) and pedagogical content knowledge, a "special amalgam of content and pedagogy (p. 8)." The traditional pedagogy in food science is lecture supported by laboratory assignments during which students apply concepts learned in lecture. The frustration expressed by faculty who felt they were losing control of their discipline was a result of the integration of communication as a pedagogical tool in their classes, a departure from their traditional lecture approach. In the cases of the faculty frustrated by the time commitment needed to integrate "related communication activities" and the faculty member who was frustrated that students working in groups did not arrive at "the conclusion I thought we were going to get to," the choice of communication as pedagogy was inconsistent with the learning goals of each individual. Agents must anticipate the integration of differing disciplines is accompanied by differing pedagogical traditions. Future research is needed to develop parameters that enable the integration of differing pedagogical traditions and devise ways that faculty can discuss implementing new pedagogy without the perception they are relinquishing their own pedagogical traditions.

Fourth, the agent of integration is a visitor to the discipline in which the integration occurs. Disciplines differ in the traditional ways students learn and the types of assignments and standards used to asses them; they may differ in the language or argument by which individuals claim their disciplinary membership (Dannels, 2001). There may also be underlying connections of the disciplines being integrated. Agents of integration must learn and appreciate the traditions of the disciplines in which they operate. The initiatives they bring to the integration must respect and value the traditions found in that discipline. After traditional methods by which groups operate in the food science discipline and profession became apparent to me, I worked to gear my suggestions to assist the faculty to achieve their learning goals for students within their traditional parameters. A research repertoire that distinguishes disciplinary traditions would provide a useful tool for agents of integration. 
Fifth, on the basis of my experience with the food science faculty, it is clear that an integration cannot be the result of a brown bag lunch (Jablonski, 2006), nor even from a series of workshops such as those I conducted, but requires an extended commitment from the agent. In an academic environment, how can agents fulfill the expectations of an integration given other faculty responsibilities? Research recognizes the necessity of institutional support for integration efforts (see for example: Baxter, Botelho, \& O’Donnell, 2015; Bhattacharya \& Hansen, 2015; Boynton, Coates, \& Reeck, 2015; Brakke, Hite, Mbughuni, Moore, \& Wade, 2015; Elrod \& Roth, 2015; Lyon, 2015; Newman et al., 2015), but how does that support extend to the agent? In my case, the integration with food science presented a research opportunity, but perhaps not everyone would view an integration assignment as an opportunity. Future research should focus closely on the overall structure that best facilitates an integration with particular attention to arrangements that make commitment of agents possible in terms of their own professional development and advancement while affording the greatest service to the integrating faculty that they in turn may benefit their students.

There are limitations to the study. First, the pre-professional programs in only one scientific discipline, food science, were the focus of the study. In line with the discussion of disciplinary influences, it would be useful to study integrations that occur in disciplines in social sciences and the humanities to determine challenges that may be specific to those areas. Second, although the faculty were well qualified to participate, their number was small and this was an integration with only one agent working with faculty from three programs. When the units of integration are larger, such as department with department or even the development of a new unit as a result of several units integrating, an important area on which to focus is to identify the issues that arise and the ways they are negotiated. Third, the baseline information revealed extends the scope of integration research and provides direction to faculty participating in integrations, but despite that the prediction was made that the results would be generalizable to other disciplines, the study does not provide documentation to support that assertion. Despite the limitations described, areas emerged that have the potential to inform future investigations of integration efforts.

\section{Conclusion}

The purpose of this investigation is to provide an initial view of the concerns of disciplinary faculty in a food science department who participated in an integration. The results of the study reveal two somewhat disparate areas of concern of the faculty participants: first were questions regarding the development and implementation of classroom activities that merged the integrated discipline with their own. The second group of concerns were personal disclosures of the participants that revealed their own personal doubts of their preparedness to develop and implement activities from another discipline into their own. According to the results of the present study, these distinct areas of concerns are those for which agents of integration must be prepared to respond.

\section{Appendix}

Note: Sample materials presented in the appendices are used by permission of the participants. 


\section{Appendix 1. Sample Public Speaking and Group Assignment.}

\section{Laboratory Presentation}

Objective: To practice oral description of food ingredients, procedures, techniques and evaluation of food products.

Directions: After preparation of the food product, discuss food science principles, sensory properties, unique aspects of preparation and relevant techniques. DO NOT describe the recipe in step-by-step detail. Each listener should review the product being presented and make comparisons to the product he/she prepared. Each listener should write one question for the speaker.

Time: 5-6 minutes with about 5 minutes for questions.

Food Science Knowledge (10 points): The speaker should explain the food science terms and concepts, function of ingredients, critical temperatures, safety considerations, and special techniques related to the product. Each listener should compare these aspects of the product presented to the product he/she prepared.

Ingredients and their functions

Terms and concepts

Temperatures

Safety

Special techniques used

Sensory Knowledge (7 points): The speaker should describe the product as if the listeners cannot see it. Did the product meet the standard characteristics? If not, what problems in preparation or technique occurred? Each listener should compare the sensory properties and standard characteristics of the product presented to the product he/she prepared.

Appearance

Texture

Flavor

Standard characteristics

Presentation Technique (8 points): The speaker should PRACTICE. The presentation should be organized and in a logical order. Speak in complete sentences, clearly, loud enough to hear, and with eye contact. Each listener should name one thing the speaker did well and give one suggestion for improvement.

You did this well:

A suggestion for improvement:

\section{Group Assignment}

Background: NASA Johnson Space Center, Houston, TX, is designing a terrestrial habitat, Bioregenerative Planetary Life Support Systems Test Complex (BIO-Plex), intended for testing Advanced Life Support (ALS) technologies, techniques, and procedures for long duration missions in space where all life support systems will be recycled and reused. ALS involves the use of hydroponically grown crops to supply and regenerate air and food for the crew. Crops grown on board will be used for air and water recycling and also serve as a food source. Space food 
development problems include weight and volume restrictions, nutrition, crew acceptability and consumption, and management of food-generated waste. One of the main challenges of long-term space flight will be to obtain a menu with sufficient variety and acceptability from a limited number of plant sources. Plants to be grown in the BIO-Plex include wheat, white potato, soybean, sweet potato, peanut, rice, tomato, lettuce, carrot, radish, spinach, strawberries, green onion, dry beans, and cabbage. Crops were selected based upon their ability to produce maximum edible biomass, to maximize space and light, as well as upon the nutrients they contain.

Objective: Your task is to develop a food product from the available ingredients. Your product should have satisfactory sensory characteristics, have few crumbs, and be easy to prepare.

Method: With your team, create a food product from the ingredients supplied to you. Your team should develop a product name, list the ingredients, and evaluate the appearance, texture, and flavor.

Rules: You have 15 minutes to develop and prepare your product. Your team will use 4 ingredients. Water, spices and herbs, salt and pepper, soy sauce, and sugar are available as resupply ingredients from earth. Select items from the following categories:

\begin{tabular}{|l|l|l|l|}
\hline \multicolumn{1}{|c|}{ Bread } & \multicolumn{1}{|c|}{ Beans “Greens” } & \multicolumn{1}{c|}{ Resupply Items } \\
\hline Tortillas & Pinto beans & Lettuce & Tomato sauce \\
\hline & Kidney beans & Radishes & Ranch dressing \\
\hline & Black beans & Green onions & Cheese \\
\hline & Soy beans & Carrots & Sour cream \\
\hline & & Tomatoes & Peanut butter \\
\hline & & Strawberries & \\
\hline
\end{tabular}

\section{Appendix 2. Sample Assessment Instruments.}

Food Preparation Presentation Evaluation

\begin{tabular}{|l|l|l|l|l|}
\hline $\begin{array}{l}\text { Ingredients, } \\
\text { functions, } \\
\text { terms, concepts }\end{array}$ & Excellent & Good & Fair & Poor \\
\hline
\end{tabular}




\begin{tabular}{|c|c|c|c|c|}
\hline 8 points & $\begin{array}{l}\text { Accurate and } \\
\text { correct } \\
\text { information. } \\
\text { Appropriate } \\
\text { scientific terms. } \\
\text { Correctly } \\
\text { answered } \\
\text { questions. }\end{array}$ & $\begin{array}{l}\text { Information } \\
\text { generally } \\
\text { accurate \& } \\
\text { correct. } \\
\text { Generally good } \\
\text { responses to } \\
\text { questions. }\end{array}$ & $\begin{array}{l}\text { Some } \\
\text { information } \\
\text { accurate, correct. } \\
\text { Incomplete } \\
\text { answers to } \\
\text { questions. }\end{array}$ & $\begin{array}{l}\text { Information is } \\
\text { inaccurate. } \\
\text { Unable to } \\
\text { answer } \\
\text { questions. }\end{array}$ \\
\hline $\begin{array}{l}\text { History, } \\
\text { temperatures, } \\
\text { food safety. }\end{array}$ & Excellent & Good & Fair & Poor \\
\hline 4 points & $\begin{array}{l}\text { Accurate and } \\
\text { correct } \\
\text { information. } \\
\text { Completely } \\
\text { discussed topics. }\end{array}$ & $\begin{array}{l}\text { Information } \\
\text { generally } \\
\text { accurate, correct. }\end{array}$ & $\begin{array}{l}\text { Some } \\
\text { information } \\
\text { accurate, correct. }\end{array}$ & $\begin{array}{l}\text { Information is } \\
\text { inaccurate. }\end{array}$ \\
\hline $\begin{array}{l}\text { Sensory } \\
\text { evaluation }\end{array}$ & Excellent & Good & Fair & Poor \\
\hline 4 points & $\begin{array}{l}\text { Appropriate } \\
\text { sensory terms. } \\
\text { Compared } \\
\text { product to } \\
\text { standard } \\
\text { characteristics. } \\
\text { Completely } \\
\text { described } \\
\text { products. }\end{array}$ & $\begin{array}{l}\text { Used some } \\
\text { sensory terms, } \\
\text { but some errors. } \\
\text { Described } \\
\text { product nearly } \\
\text { completely. }\end{array}$ & $\begin{array}{l}\text { Used sensory } \\
\text { terms, but some } \\
\text { inaccurately. } \\
\text { Omitted many } \\
\text { aspects of } \\
\text { product } \\
\text { description. }\end{array}$ & $\begin{array}{l}\text { No sensory } \\
\text { evaluation. }\end{array}$ \\
\hline $\begin{array}{l}\text { Presentation } \\
\text { technique }\end{array}$ & Excellent & Good & Fair & Poor \\
\hline 8 points & $\begin{array}{l}\text { Logical order. } \\
\text { Spoke clearly, in } \\
\text { complete } \\
\text { sentences, } \\
\text { appropriate } \\
\text { volume. Good } \\
\text { eye contact. } \\
\text { Appropriate } \\
\text { pacing. }\end{array}$ & $\begin{array}{l}\text { Problems with } \\
\text { organization. } \\
\text { Generally spoke } \\
\text { clearly, good eye } \\
\text { contact. May be } \\
\text { too fast or slow. }\end{array}$ & $\begin{array}{l}\text { Unprepared. } \\
\text { Difficult to } \\
\text { understand or } \\
\text { hear. Too fast or } \\
\text { slow. }\end{array}$ & $\begin{array}{l}\text { Not well } \\
\text { planned, } \\
\text { unorganized. } \\
\text { Unclear, difficult } \\
\text { to understand } \\
\text { and follow. Too } \\
\text { fast or slow. }\end{array}$ \\
\hline
\end{tabular}

Group Activity Rubric

\begin{tabular}{|c|c|c|c|c|c|}
\hline Quality & A & B & C & D & F \\
\hline $\begin{array}{l}\text { I feel part of } \\
\text { this team. }\end{array}$ & Completely & $\begin{array}{c}\text { Most of the } \\
\text { time }\end{array}$ & $\begin{array}{c}\text { On the edge, } \\
\text { sometimes in }\end{array}$ & $\begin{array}{c}\text { Generally } \\
\text { outside }\end{array}$ & $\begin{array}{c}\text { Outside, not } \\
\text { really a part }\end{array}$ \\
\hline
\end{tabular}




\begin{tabular}{|c|c|c|c|c|c|}
\hline $\begin{array}{l}\text { How safe is it } \\
\text { to be at ease, } \\
\text { relaxed, } \\
\text { myself in this } \\
\text { team? }\end{array}$ & $\begin{array}{l}\text { Perfectly safe } \\
\text { to be myself }\end{array}$ & $\begin{array}{l}\text { Most people } \\
\text { accept me }\end{array}$ & $\begin{array}{l}\text { I have to be } \\
\text { careful in } \\
\text { what I say or } \\
\text { do }\end{array}$ & $\begin{array}{c}\text { I am quite } \\
\text { fearful to be } \\
\text { myself }\end{array}$ & $\begin{array}{c}\text { No way can I } \\
\text { be myself }\end{array}$ \\
\hline $\begin{array}{l}\text { How } \\
\text { effective is } \\
\text { our team } \\
\text { using } \\
\text { everyone's } \\
\text { ideas to make } \\
\text { decisions? }\end{array}$ & $\begin{array}{c}\text { All ideas } \\
\text { given fair } \\
\text { hearing }\end{array}$ & $\begin{array}{c}\text { Generally } \\
\text { good } \\
\text { participation }\end{array}$ & $\begin{array}{c}\text { Only } \\
\text { sometimes do } \\
\text { we hear from } \\
\text { all }\end{array}$ & $\begin{array}{c}\text { Only a few } \\
\text { members } \\
\text { share ideas }\end{array}$ & $\begin{array}{c}\text { We never get } \\
\text { group } \\
\text { discussion }\end{array}$ \\
\hline $\begin{array}{l}\text { How well } \\
\text { does the team } \\
\text { work at } \\
\text { tasks? }\end{array}$ & $\begin{array}{c}\text { Work well, } \\
\text { good } \\
\text { progress }\end{array}$ & $\begin{array}{c}\text { Generally } \\
\text { good pace of } \\
\text { work }\end{array}$ & $\begin{array}{c}\text { Slow } \\
\text { progress; } \\
\text { spurts of } \\
\text { work }\end{array}$ & $\begin{array}{c}\text { Little } \\
\text { progress: } \\
\text { most } \\
\text { members loaf }\end{array}$ & $\begin{array}{l}\text { Coasts: } \\
\text { makes no } \\
\text { progress }\end{array}$ \\
\hline $\begin{array}{l}\text { What is the } \\
\text { level of } \\
\text { responsibility } \\
\text { for work on } \\
\text { our team? }\end{array}$ & $\begin{array}{l}\text { Each person } \\
\text { assumes } \\
\text { responsibility }\end{array}$ & $\begin{array}{c}\text { Most } \\
\text { members are } \\
\text { responsible }\end{array}$ & $\begin{array}{c}\text { Half are } \\
\text { responsible; } \\
\text { half aren’t }\end{array}$ & $\begin{array}{l}\text { Only one } \\
\text { member is } \\
\text { responsible }\end{array}$ & $\begin{array}{c}\text { Nobody } \\
\text { really } \\
\text { assumes } \\
\text { responsibility }\end{array}$ \\
\hline $\begin{array}{l}\text { How are } \\
\text { differences or } \\
\text { conflicts } \\
\text { handled on } \\
\text { our team? }\end{array}$ & $\begin{array}{l}\text { Recognized } \\
\text { \& worked } \\
\text { through by } \\
\text { the team }\end{array}$ & $\begin{array}{l}\text { Recognized; } \\
\text { some effort } \\
\text { to deal with } \\
\text { them by the } \\
\text { team }\end{array}$ & $\begin{array}{l}\text { Recognized; } \\
\text { only some } \\
\text { members try } \\
\text { to deal with } \\
\text { them }\end{array}$ & $\begin{array}{l}\text { Recognized } \\
\text { but mostly } \\
\text { remain } \\
\text { unresolved }\end{array}$ & $\begin{array}{c}\text { Denied, } \\
\text { suppressed, } \\
\text { or avoided at } \\
\text { all costs }\end{array}$ \\
\hline
\end{tabular}

In the space below, give one or two specific suggestions for how your team can improve its functioning. Since we know that no one is perfect, "our group is doing just fine," or "no suggestions for improvement” are not acceptable answers here. Your suggestions will be given back to your group so that you can consider them as you gear up for the special project.

\section{Group Activity Self-Reflection Assessment}

So far this semester, your group has worked mostly as two sets of partners, with the partners changing for each experiment. Think about your experiences with three different partners and also in your whole group as you answer the following questions:

1. Assess your own contributions to the activities of your partnership. What did you do well? What would need improvement? Be as specific as possible, e.g. "I was always on time and prepared for the lab." "I tended to sit back and let my partner do most of the work."

2. How did your contributions change as you changed partners? (Again, be specific, e.g. "I was the leader with one partner but responsibilities were shared equally with the others.”)

3. Give one or two examples of good vs. not-so-good interactions that you had with a partner. 
4. Give one specific example of something you learned from your group that you probably wouldn't have learned on your own.

5. Based on your experiences so far, what changes (if any) do you want to make in the ground rules that your group wrote earlier?

\section{References}

American Association of Colleges and Universities. (2015). Integrative learning. Retrieved from www.aacu.org/resources/integrative-learning

American Association of Colleges and Universities and The Carnegie Foundation for the Advancement of teaching. (2004). A statement on integrative learning. Retrieved from http://www.evergreen.edu/washingtoncenter/docs/intlearning/statementintlearning.pdf

American Dietetics Association. (2009). Eligibility requirements and accreditation standards for dietetic programs in dietetics (DPD). Retrieved from http://www.eatright.org/uploadedFiles/CADE/Accreditation/DPD_2008_ERAS_v0-1_2009-0718_1200.pdf

Baxter, S., Botelho, J., \& O’Donnell, K. (2015). STEM student success through system wide coordination. Peer Review, 17. Retrieved from www.aacu.org/peerreview/2015/spring/Baxter

Bhattacharya, B. \& Hansen, D. (2015). Implementing a summer STEM bridge program. Peer Review, 17. Retrieved from www.aacu.org/peerreview/2015/spring/bhattacharya

Bordoloi, L. M. \& Winebrake, J.J. (2015, April 27). Bringing the liberal arts to engineering education. The chronicle of higher education. Retrieved from www.chronicle.com/article/Bringing-the-Liberal-Arts-to/229671

Boyer, E. L. (1990). Scholarship reconsidered: Priorities of the professorate. New York: The Carnegie Foundation for the Advancement of Teaching.

Boynton, E., Coates, L., Reeck, L. (2015). Opening the doors for faculty collaboration: The case of the Alleghany getaway. Peer Review, 16/17. Retrieved from www.aacu.org/peerreview/20142015/fall-winter/boynton

Brakke, K., Hite, M.S., Mbughuni, H., Moore, O., Wade, B. \& Phillips, M.T. (2015). Our beloved journey: Using storytelling to foster faculty community. Peer Review, 16/17. Retrieved from www.aacu.org/peerreview/2016/2017/brakke

Cannon, W., \& Doyle, D. (2005). Writing and speaking across the curriculum: A guidebook for planning and implementation. Unpublished manuscript, Central College, Pella, IA.

Cannon, W. \& Roberts, C. (1981, March). Across the curriculum: The communication skills program at Central College. Paper presented at the American Association for Higher Education, Washington, D.C.

Carnegie Foundation for the Advancement of Teaching (2004). What is integrative learning? Retrieved from http://gallery.carnegiefoundation.org/ilp/what-is-ILP.htm 
Considine, J. R., Mihalick, J. E., Mogi-Hein, Y.R., Penick,-Parks, M. P., Van Auken, P. M. (2014). "Who am I to bring diversity into the classroom?" Learning communities wrestle with creating inclusive college classrooms. Journal of the Scholarship of Teaching and Learning, 14, 18-30. DOI: $10.14434 /$ josotl.v14.i4.3895

Cronin, M., \& Grice, G. (1993). A comparative analysis of training models versus consulting/training models for implementing oral communication across the curriculum. Communication Education, 42, 1-9.

Cronin, M., Grice, G., \& Palmerton, P. (2000). Oral communication across the curriculum: The state of the art after twenty-five years of experience. Journal of the Association for Communication Administration, 29, 66-87.

Dalrymple, J. \& Miller, W. (2006). Interdisciplinarity: A key for real world learning. Planet, 17, 29-31. DOI: 10/11120/plan.2006.00170029

Dannels, D. P. (2001). Time to speak up: A theoretical framework of situated pedagogy and practice for communication across the curriculum. Communication Education, 50, 144- 158.

DOI: $10.1080 / 03634520109379240$

Dannels, D. P. (2002). Communication across the curriculum and in the disciplines: Speaking in engineering. Communication Education, 51, 254-268. DOI: 10.1080/03634520216513

Dannels, D. P. (2003). Teaching and learning design presentations in engineering: Contradictions between academic and workplace activity systems [Electronic version]. Journal of Business and Technical Communication, 17, 139-169. DOI: 10.1177/1050651902250946

Dannels, D. P. (2005). Performing tribal rituals: A genre analysis of “crits” in design studios. Communication Education, 54, 136-160. DOI: 10.1080/03634520500213165

Dannels, D. P. (2010). Communication across the curriculum problematics and possibilities: Standing at the forefront of education reform. In D. L. Fassett \& J. T. Warren (Eds.), The Sage Handbook of Communication and Instruction (pp. 55-79). Thousand Oaks, CA: Sage.

Dannels, D. P., Anson, C. M., Bullard, L., \& Peretti, S. (2003). Challenges in learning communication skills in engineering. Communication Education, 52, 50-56. DOI: 10.1080/03634520302454

Dannels, D. P., Gaffney, A., \& Martin, K. (2008). Beyond content, deeper than delivery: What critique feedback reveals about communication expectations in design education. International

Journal for the Scholarship of Teaching and Learning, 2. Retrieved from http://academics.georgiasouthern.edu/ijsotl/v2n2/articles/PDFs/Article_Dannels_et_al.pd f

Dannels, D. P., \& Housley Gaffney, A. L. (2009). Communication across the curriculum and in the disciplines: A call for scholarly cross-curricular advocacy. Communication Education, 58, 124-153. DOI: 10.1080/03634520802527288

Dannels, D. P., \& Norris-Martin, K. (2008). Critiquing critiques: A genre analysis of feedback across novice to expert design studios. Journal of Business and Technical Communication, 22, 135-159. DOI: 10.1177/1050651907311923 
Darling, A. L. (2005). Public presentations in mechanical engineering and the discourse of technology. Communication Education, 54, 20-33. DOI: 10.1080/03634520500076711

Darling, A. L., \& Dannels, D. P. (2003). Practicing engineers talk about the importance of talk: A report on the role of oral communication in the workplace. Communication Education, 52, 116. DOI: $10.1080 / 03634520302457$

Elrod, S. \& Roth, M. (2015). Framing leadership for sustainable interdisciplinary programs. Peer Review, 17. Retrieved from www.aacu.org/peerreview/2015/spring/roth

Housley Gaffney, A. L. (2015). Uncovering embedded face threat mitigation in landscape architecture critique feedback. Journal of the Scholarship of Teaching and Learning, 15, 110-125. DOI: http://dx.doi.org/10.14434/josotl/v.15i4.13456

Hovland, K., Anderson, C. \& Ferren, A. (2015). Interrogating integrative learning. Peer Review, 16/17. Retrieved from www.aacu.org/peerreview/2014-2015/fall-winter/hovland

Huber, M. T. (2002). Disciplinary styles in the scholarship of teaching: Reflections on the academy for the scholarship of teaching and learning. In M.T. Huber \& S. P. Morreale (Eds.), Disciplinary styles in the scholarship of teaching and learning: Exploring common ground (pp. 25-43). Washington, DC: American Association for Higher Education.

Huber, M. T., \& Hutchings, P. (2004). Integrative learning: Mapping the terrain. Washington, DC: American Association of Colleges and Universities. Retrieved from http://archive.carnegiefoundation.org/pdfs/elibrary/elibrary_pdf_636.pdf

Huber, M.T., Hutchings, P., Gale, R. (2005). Integrative learning for liberal education. Peer Review, 7. Retrieved from www.aacu.org/publications-research/periodicals/integrative-learning$\underline{\text { liberal-education }}$

Huber, M. T. \& Morreale, S. P. (2002). Situating the scholarship of teaching and learning: A cross-disciplinary conversation. In M. T. Huber \& S. P. Morreale (Eds.), Disciplinary styles in the scholarship of teaching and learning: Exploring common ground (pp. 1-24). Washington, DC: American Association for Higher Education.

Institute of Food Technologists. (2011). IFT: Undergraduate education standards for degrees in food science, 2001 revision. Retrieved from http://www.ift.org/community/students/approvedundergrad-programs/education-standards.aspx

Jablonski, J. (2006). Academic writing consulting and WAC: Methods and models for guiding cross-curricular literacy work. Cresskill, NJ: Hampton Press.

Kern, B., Mettetal, G., Dixson, M., \& Morgan, R. K. (2015). The role of SOTL in the academy: Upon the $25^{\text {th }}$ anniversary of Boyer's Scholarship Reconsidered. Journal of the Scholarship of Teaching and Learning, 15, 1-14. DOI: http://dx.doi.org/10.14434/josotl.v15.i3.13623

Klein, J. T. (2005). Integrative learning and interdisciplinary studies. Peer Review, 7, 8-10. Retrieved

from http://www.academia.edu/755632/Integrative_learning_and_interdisciplinary_studies 
Lyon, L.J. (2015). Development of teaching expertise viewed through the Dreyfus Model of Skill Acquisition, Journal of the Scholarship of Teaching and Learning, 15, 88-105. DOI: http://dx.doi.org/10.14434.josotl.v15i1.12866

Miles, M. \& Huberman, A. (1994). Qualitative data analysis (2 ${ }^{\text {nd }}$ ed.).Thousand Oakes, CA: Sage.

Morton, J. (2006). The integration of images into architecture presentations: A semiotic analysis. Art, Design, \& Communication in Higher Education, 5, 21-37. DOI: 10.1386/adch.5.1.21/1

Morton, J., \& O’Brien, D. (2005). Selling your design: Oral communication pedagogy in design education. Communication Education, 54, 6-19. DOI: 10.1080/03634520500076885

Morreale, S., Shockley-Zalabak, P., \& Whitney, P. (1993). The center for excellence in oral communication: Integrating communication across the curriculum. Communication Education, 42, 10-21.

Newman, L.E., Carpenter, S., Grauwe, N. \& Jaret-McKinstry, S. (2015). Creating a culture conducive to integrative learning. Peer Review, 16/17. Retrieved from www.aacu.org/peerreview/2014-2015/fall-winter/newman

Patton, M.Q. (2002). Qualitative research and evaluation methods ( ${ }^{\text {rd }}$ ed.). Thousand Oaks, CA: Sage.

Price, M. (2011). Promoting psychology as a STEM discipline. Monitor on Psychology, 42, 32.

Reinard, J. C. (2008). Introduction to communication research (4 ${ }^{\text {th }}$ ed.). Boston, MA: McGrawHill Higher Education.

Reitmeier, C. and Vrchota, D. (2009). Self-assessment of oral communication presentations in Food Science and Human Nutrition. Journal of Food Science Education, 8, 88-92. DOI: 10.1111/j.1541-4329.2009.00080.x

Saldana, J. (2009). The coding manual for qualitative researchers. Thousand Oaks, CA: Sage.

Shulman, L. (1987). Knowledge and teaching: Foundations of the new reform. Harvard Educational Review, 57, 1-22.

Smith, E. R. (2005). Learning to talk like a teacher: Participation and negotiation in co-planning discourse. Communication Education, 54, 52-71. DOI: 10.1080/03634520500076778

Steinfatt, T. (1986). Communication across the curriculum. Communication Quarterly, 34, 460470.

Strohmeier, M., Novak, D., Stratton, M., \& Leipzig, J. (1992). Implementing speaking across the curriculum: A case study. Association for Communication Administration Bulletin, 81, 32-52.

Tracy, S. J. (2013). Qualitative research methods: Collecting evidence, crafting analysis, communicating impact. UK: John Wiley \& Sons.

Vrchota, D. (2011). Communication in the disciplines: Interpersonal communication in dietetics. Communication Education, 60, 210-230. DOI: 10.1080/03634523.2010.523475 
Vrchota, D. A. (2015a). Cross-curricular consulting: How WAC experts can practice adult learning theory to build relationships with disciplinary faculty. The WAC Journal, 26, 56-75.

Vrchota, D. A. (2015b). A view of oral communication activities in food science from the perspective of a communication researcher. Journal of Food Science Education, 14, 36-47. DOI: 10.1111/1541-4329.12056

Weiss, R. (1990, November). The faculty development component of speaking across the curriculum. Paper presented at the annual meeting of the National Education Association, Chicago, IL (ERIC Document Reproduction Service No. ED327893). 